\title{
Cerai Lebe sebagai Inisiatif Lokal dalam Upaya Meminimalisir Praktek Perceraian Liar (Studi Kasus di Desa Cangkring Kabupaten Indramayu)
}

\author{
Wardah Nuroniyah \\ Fakultas Syariah dan Ekonomi Islam IAIN Syekh Nurjati \\ Jl. Perjuangan By Pass Cirebon \\ E-mail:wardah.faza@syekhnurjati.ac.id
}

$\begin{array}{llll}\text { Submit } & : 27 \text { Maret } 2020 & \text { Diterima } & : \text { 18 Mei 2020 } \\ \text { Revisi } & : 10 \text { April } 2020 & \text { Terbit } & : \text { 03 Juni 2020 }\end{array}$

\begin{abstract}
Abstrak: Perceraian di luar pengadilan banyak terjadi pada masyarakat di Desa Cangkring Kabupaten Indramayu. Uniknya di desa ini Lebe (pembantu pegawai pencatat nikah) menjadi fasilitator dalam hal persoalan perceraian termasuk juga dalam hal menangani secara administratif data masyarakat yang telah bercerai tanpa mengajukan ke Pengadilan Agama. Melalui studi yuridis sosiologis perceraian melalui Lebe dapat dipahami sebagai pilihan bagi masyarakat dalam menyelesaikan konflik yang ada dalam perkawinan, baik itu alasan individu, letak geografis desa yang jauh dari pengadilan, faktor ekonomi, perkawinan usia dini, sumber daya manusia rendah, ataupun kondisi sosial budaya setempat yang mempengaruhi seorang untuk menyelesaikan perceraian melalui Lebe. Berdasarkan teori aksi sosial (action theory) oleh Talcott Parsons aktor-aktor yang memilih perceraian melalui Lebe karena dianggap lebih mudah untuk mencapai tujuannya yaitu perceraian. Cerai Lebe di desa Cangkring dimaksudkan untuk menertibkan ketentraman dan perlindungan hukum terhadap masyarakat yang memiliki tingkat perceraiannya sangat tinggi. Masyarakat diberi kemudahan karena aturan-aturan dalam Cerai Lebe tidak serumit proses perceraian di Pengadilan Agama.
\end{abstract}

Kata Kunci: Cerai, Lebe, perkawinan, di luar pengadilan

Abstract: There are a lot of divorce conducted outside the court occurs in Cangkring Village, Indramayu Regency. Uniquely in this village Lebe (a marriage registrar officer) became a facilitator in matters of divorce including in terms of handling administratively the data of divorced couples without submitting to the Religious Courts. Through a socio-juridical study, it is understandable as a choice for the community in resolving conflicts in marriages. There are any reasons for choosing divorce by Lebe, the individual reasons, such as geographical location of the village that far from the court, economic factors, early marriage, low human resources, or local socio-cultural conditions that affect a person to do divorce through the Lebe. Based on the theory of social action by Talcott Parsons, the actors who chose divorce through Lebe are considered easier to achieve its goal of divorce. Divorce by Lebe in Cangkring village is intended to curb peace and legal protection for the people who have a very high divorce rate. The community was given convenience because the rules in divorce are not as complicated as the divorce process in the Religious Court, even though it is considered illegal.

Keywords: Divorce, Lebe, marriage, extrajudicial 


\section{凡L-Manāhij}

\section{Pendahuluan}

Secara umum, pengaturan masalah perceraian di Indonesia terdapat dalam Undang-Undang No.1 Tahun 1974 tentang Perkawinan, Undang-Undang No. 7 Tahun 1989 tentang Peradilan Agama, Peraturan Pemerintah No. 9 Tahun 1975 tentang Pelaksanaan Undang-Undang No. 1 Tahun 1974 tentang Perkawinan, dan Instruksi Presiden No. 1 Tahun 1991 tentang Kompilasi Hukum Islam (KHI). Pengadilan Agama pada dasarnya menjadi tempat bagi terjadinya perselisihan hukum keluarga yang terjadi di antara umat Islam. Dalam kaitannya dengan hukum perkawinan, KHI memberi wewenang Pengadilan Agama untuk menyelesaikan masalah perselisihan antara lain permasalahan perceraian, harta bersama, masalah hadhanah, dan lainnya. Adanya Pengadilan Agama sebagai tempat perselisihan dalam perkawinan menunjukkan bahwa lembaga pemerintah tidak hanya berupaya turut serta mewujudkan tujuan perkawinan ketika pada awal akad nikah, tetapi juga mengawalnya selama masa pernikahan. ${ }^{1}$ Kalaupun perkawinan tidak dapat dipertahankan, maka lembaga pemerintah juga menjaga hak masing-masing, terutama hak-hak yang dimiliki isteri dan anak yang menyangkut nafkah dan harta perkawinan. Putusan pengadilan terhadap perselisihan perkawinan tersebut mengikat para pihak yang berperkara, sebagaimana kaidah hukm al-häkim mulzimun wa yarfa'u al-khiläf (keputusan hakim itu mengikat dan menghilangkan perselisihan). Perceraian yang dilakukan dalam sidang Pengadilan dapat memberi perlindungan hukum terhadap mantan isteri dan anak-anak mereka. Hak-hak mantan isteri dan anak dapat terpenuhi karena mempunyai kekuatan hukum yang tetap. Sedangkan perceraian yang tidak dilakukan di depan sidang Pengadilan tidak dapat memberi kepastian hukum terhadap mantan isteri dan anak-anak mereka. Hak-hak isteri dan anak yang ditinggalkan pun tidak terjamin secara hukum. Hal ini juga menyebabkan mantan suami atau mantan isteri tidak dapat menikah lagi dengan orang lain secara sah menurut hukum positif.

Oleh karena itu perlu adanya campur tangan Pemerintah yang sepenuhnya diserahkan kepada Pengadilan guna mencegah hal-hal yang tidak diinginkan. Akan tetapi, masih banyak masyarakat yang melakukan perceraian di luar sidang Pengadilan. Perceraian di luar sidang ini juga terjadi pada sebagian masyarakat muslim di Desa Cangkring Kabupaten Indramayu yang termasuk Desa yang cukup maju. Uniknya di desa ini yang berbeda dengan masyarakat lainnya antara lain, jika cerai liar pada masyarakat umumnya terjadi begitu saja antara suami dan isteri dirumah masing-masing, tetapi di desa cangkring ini Lebe (pembantu pegawai pencatat nikah) menjadi fasilitator dan media dalam hal persoalan perceraian di desa tersebut termasuk juga dalam hal menangani secara administratif data masyarakat yang telah bercerai tanpa mengajukan ke Pengadilan Agama.

Berdasarkan survei awal yang penulis lakukan, ada sebagian masyarakat yang lebih memilih bercerai di depan Lebe dibanding bercerai dalam sidang Pengadilan Agama. Adapun penyebab terjadinya perceraian didepan Lebe di Desa Cangkring Kabupaten Indramayu, banyak dilatar belakangi oleh berbagai faktor. Salah satu faktor perceraian Lebe tersebut dikarenakan sulitnya melakukan pengurusan perceraian di Pengadilan Agama yang membutuhkan waktu yang lama, serta banyak mengeluarkan biaya. Terjadi dualisme hukum di Indonesia yang tak kunjung terselesaikan. Hukum positif disatu pihak dan hukum agama (adat/hukum yang dipraktekan oleh masyarakat) dipihak lain. Di dalam doktrin fikih dianggap telah jatuh talaknya, sedangkan dalam undang-undang belum jatuh

Bani Syarif Maula, Sosiologi Hukum Islam Di Indonesia: Studi Tentang Realitas Hukum Islam Dalam Konfigurasi Sosial Dan Politik (Malang: Aditya Media, 2010), 16. 
talaknya karena tidak dilakukan di depan Pengadilan. ${ }^{2}$ Bukankah hukum yang baik adalah norma yang antisipatif, responsif, mampu beradaptasi dan mengakomodasi perubahan yang terjadi dan kebutuhan masyarakat, tidak disangkal hukum sebagai norma adalah realitas ideal. ${ }^{3}$

Berdasarkan latar belakang masalah di atas, tulisan ini membahas beberapa permasalahan, yaitu bagaimana penyelesaian kasus Cerai Lebe di desa Cangkring Kabupaten Indramayu, faktor apa saja yang melatar belakangi terjadinya Cerai Lebe dan apa dampaknya dalam masyarakat Desa Cangkring Indramayu, serta bagaimana analisis secara yuridis sosiologis terhadap Cerai Lebe di Desa Cangkring Indramayu. Dengan beberapa permasalahan tersebut, tulisan ini bertujuan sebagai pengembangan wawasan terkait permasalahan sosiologis dalam hal praktek-praktek hukum yang hidup dalam masyarakat, terutama bentuk-bentuk perceraian yang dipraktekkan oleh masyarakat terkait cerai di luar pengadilan, dan memberikan alternatif solusi dan kontribusi pemikiran terutama dalam kajian yuridis sosiologis dalam hal ini terkait perceraian.

Pembahasan dalam kajian ini dilakukan dengan pendekatan yuridis sosiologis. Pendekatan sosial dipergunakan untuk menganalisis sikap, pandangan dan tindakan aktor dalam praktik pelaksanaan Cerai Lebe. Sedangkan pendekatan yuridis normatif dipergunakan untuk menganalisis norma peraturan perundang-undangan dengan mengacu pada nilai-nilai kesejahteraan dan keadilan dalam masyarakat.

\section{Analisis Faktor dan Dampak Cerai Lebe di Desa Cangkring}

Dalam kehidupan bermasyarakat dan bernegara, perkawinan dan keluarga merupakan sebuah institusi yang sangat penting. Dengan adanya perkawinan maka akan ada konsekuensi yang oleh karena itu ada aturan-aturan atau prosedur guna menghindari kemungkinan-kemungkinan negatif yang tidak terduga yang akan merugikan berbagai pihak, begitu halnya dengan perceraian. Di antara prosedur dan aturan yang dibuat bagi masyarakat Islam di Indonesia adalah bahwa perkawinan itu harus dicatatkan secara resmi dan dipublikasikan dan perceraian pun harus disahkan melalui Pengadilan Agama. Namun kenyataan yang terjadi di tengah-tengah masyarakat Islam di Indonesia, tidak semua mengikuti aturan-aturan pemerintah tersebut, dengan kata lain ada pembangkangan-pembangkangan dan penyimpangan-penyimpangan yang dilakukan, baik itu oleh pelaku perkawinan dan perceraian atau pun oleh pihak Kelurahan dan pembantu PPN itu sendiri.

Problematika talak di luar pengadilan ini sudah ada dari zaman dahulu, sebagaimana terlihat dari fakta sejarah di Era Orde Lama dan Orde Baru, dalam latar belakang terbentuknya UU No. 1 tahun 1974 tentang Perkawinan, dimana adanya tuntutan yang dikumandangkan sejak kongres perempuan Indonesia pada tahun 1928 agar ada perbaikan terhadap kedudukan wanita Islam (penduduk asli) dalam perkawinan terutama menyangkut hak dan kewajibannya diatur dalam hukum tertulis. Hukum perkawinan orang asli Indonesia yang beragama Islam tertuang dalam fikih tapi fikih tidak tergolong kepada hukum yang tidak tertulis sebagai undang-undang, dan masalah-masalah yang menjadi persoalan pada waktu itu adalah kawin Paksa, poligami dan talak yang sewenang-wenang. ${ }^{4}$ Menurut Dr. Hammudah Abd al-Alti, talak adalah semacam perceraian

\footnotetext{
Arskal Salim, Demi Keadilan Dan Kesetaraan (Jakarta: Puskumham dan Asia Foundation, 2009), 60.

Hans Kelsen, Pengantar Teori Hukum (Bandung: Nusa Media, 2010), 47.

M. Daud Ali, Hukum Islam Dan Peradilan Agama (Jakarta: Raja Grafindo Persada, 2002), 21.
} 
sederhana yang bisa dirujuk atau simple revocable divorce. Pada dasarnya hanya sekedar menyatakan ketidaksenangan dan kekesalan suami semata, bukan untuk mengakhiri perkawinan. Tapi dalam kehidupan masyarakat, talak telah dijadikan secara efektif untuk memecahkan perkawinan, sudah barang tentu penyelewengan tersebut tidak bisa dibiarkan berlanjut demi untuk menertibkan dan mensejahterakan keluarga masyarakat Islam Indonesia, oleh karena itulah lahirnya UU No. 1 Tahun 1974 untuk menertibkan talak dengan melibatkan Pengadilan Agama dan tidak dibenarkan adanya perceraian liar. ${ }^{5}$ Hal ini menunjukkan apakah masalah perceraian luar pengadilan sudah menjadi budaya hukum yang mengental dalam masyarakat bangsa Indonesia sejak dahulu kala sampai sekarang. ${ }^{6}$ Dengan demikian, hal tersebut tidak menutup kemungkinan banyaknya perceraian luar pengadilan di tengah masyarakat seperti di Desa Cangkring, karena melihat kenyataan masyarakat lebih banyak memilih dengan melakukan perceraian melalui lebe dari pada pergi ke Pengadilan Agama. Karena secara agama sudah dianggap sah, tapi dampaknya lebih besar dalam kehidupan bermasyarakat. Dan tidak menutup kemungkinan implementasi dari Kompilasi Hukum Islam yang dijadikan hukum materil di Pengadilan Agama bersifat instruksi dalam kedudukan sebagai sumber hukum formil kurang kuat.

\section{Faktor-faktor terjadinya Cerai Lebe di Desa Cangkring}

Berdasarkan hasil observasi dan wawancara penulis, ditemukan beberapa faktor yang menyebabkan terjadinya Cerai Lebe, yaitu:

a. Perkawinan Usia Dini

Terjadinya pernikahan usia dini disebabkan kedua calon mempelai hanya tamat Sekolah Dasar, merekaberalasan mengapa mereka menikah dalam usia muda, karena tidak rangkayang ditunggu kalau mereka sekolah berarti nunggu tamat sekolah. Karena tidak ada yang ditunggu lebih baik mereka melangsungkan pernikahan. Namun sangat disayangkan tidak jarang perkawinan usia muda ini berujung ke perceraian. Umur masih muda pemikiran belum matang dan dibarengi oleh kurangnya ilmu pengetahuan agama Islam. Umur yang ditentukan oleh UU No. 1 Tahun 1974 perempuan minimal 16 tahun dan laki-laki 19 tahun (perubahan dalam amendemen UU No. 1 tahun 1974 baik laki-laki maupun perempuan boleh mennikah jika sudah berusia 19 tahun), dan menurut Kompilasi Hukum Islam calon mempelai yang belum mencapai umur 21 tahun harus mendapat izin sebagaimana yang diatur dalam pasal ayat (2), (3), (4), dan (5) UU No. 1 Tahun $1974 .^{7}$

b. Sumber Daya Manusia Rendah

Karena tidak sekolah setelah tamat Sekolah Dasar, dapat memicu untuk melakukan perkawinan dini, dan tidak jarang terjadinya perceraian, disebabkan pemikirannya belum matang apa lagi tidak dibarengai dengan ilmu pengetahuan agama, yang istilahnya "Buto Kayu". Sesuai dengan hasil wawancara peneliti dengan Bapak Supardi:

\footnotetext{
M. Shodiq and Shalahuddin Chaery, Kamus Istilah Agama: Memuat Berbagai Istilah Agama Dari Alquran Hadits Dll. (Jakarta: Sienttarama, 1991), 358. M. Yahya Harahap, Kedudukan Kewenangan Dan Acara Peradilan Agama UU No. 7 Tahun 1989 (Jakarta: Sinar Grafika, 2007), 215.

6 Harahap, Kedudukan Kewenangan Dan Acara Peradilan Agama UU No. 7 Tahun 1989, 215.

7 Undang-Undang Nomor 1 Tahun 1974 Tentang Perkawinan. Instruksi Presiden Nomor 1 Tahun 1991 Tentang Kompilasi Hukum Islam Di Indonesia.
} 
"Di desa ini banyak terjadi perkawinan dini, sebab banyak yang tamat SD saja tidak melanjutkan pendidikan yang lebih tinggi, umur pernikahan antara 13, 14-17 tahun. Alasan karena daripada menganggur, atau karena ekonomi orang tua yang kurang memadai, bila salah satu anaknya ada yang menikah berarti dapat mengurangi tanggung jawabnya."

Tanpa pendidikan susah untuk merubah paradigma dan budaya masyarakat, paradigma yang statis menjadi salah satu sebab bertahannya budaya dan adat apa lagi adat dan budaya yang tidak prospektif. ${ }^{9}$ Dengan kondisi masyarakat yang seperti ini, kadangkala rumah tangga tidak bisa bertahan sampai akhir hayat, sesuai dengan apa yang diungkapkan oleh bapak Pembantu Penghulu (Lebe):

"Satu tahun bisa terjadi perkawinan sebanyak 25 pasangan suami-isteri, dari jumlah ini terkadang ada lima atau lebih pasangan yang talak liar, alasan mereka tidak mau talak di depan sidang Pengadilan Agama, karena biaya mahal, lama prosesnya, sesekali datang sidang keliling dari pihak Pengadilan Agama ke desa ini. Tapi sepertinya sudah menjadi budaya masyarakat setempat bila terjadi perceraian dilakukan dengan talak liar, kawin cerai sudah dianggap hal yang biasa.Talak liar yang tidak dilandasi dengan akta talak, dapat membuat seseorang bertindak semaunya saja terhadap isteri. Oleh karena itu kami sebagai pihak yang bertanggung jawab maka demi kemaslahatan dan ketertiban masyarakat, mengharuskan perceraian dilakukan dan dicatatkan di desa"10

c. Masalah Ekonomi

Kebutuhan rumahtangga dewasa ini sangat meningkat, disamping kebutuhan pangan juga terdapat juga gaya hidup yang tinggi. Untuk itu, suami dituntut untuk memenuhi kebutuhan tersebut, tapi kadangkala usaha suami tidak sesuai dengan pengeluaran keuangan rumah tangga dan tidak heran juga isteri ikut andil mencari nafkah. Bila faktor ekonomi ini tidak terpenuhi secara maksimal dapat memicu terjadinya perceraian. Di samping itu, terdapat juga faktor perceraian dimana sang isteri senang melakukan perkeriditan dalam memenuhi kebutuan peralatan rumah tangga, sehingga sulit untuk dibayar sebagaimana peristiwa AM dengan Ny. Mmengatakan:

"Alasan saya mentalak isteri saya karena dia selalu berhutang di sana sini secara kredit, saya sudah pernah membayarnya dengan meminjam uang di bank, kemudian muncul lagi hutang baru, dan saya nasehati dan dipanggil orang tuanya untuk mencari jalan keluar, ternyata orang tuanya kurang peduli karena kesal melihat tingkah laku anaknya, rasanya tidak ada jalan lain hanya saya bertekad untuk berpisah."11

Merantau ke Malaysia sebagai TKI banyak dilakukan oleh laki-laki maupun perempuan. Mereka merantau untuk menacari nafkah, karena tinggal di desa sebagai petani tidak akan mencukupi kebutuhan hidup keluarga. Suami atau isteri yang merantau ke Malaysia menjadi faktor terjadinya perceraian, karena jarak yang jauh antara suami dan istri sehingga ada fungsi keluarga yang tidak bisa dijalankan seperti fungsi afeksif, fungsi perlindungan dan fungsi seksual. Konflik keluarga yang terjadi selama salah satu pasangannya merantau ke Malaysia menyebabkan pasangan

8 Wawancara dengan Kepala Desa Cangkring, 14 September 2018

9 Nasution Khoiruddin, Hukum Perdata (Keluarga Islam Indonesia) Dan Perbandingan Hukum Perkawinan Di Dunia Muslim (Yogyakarta: Academia - Tazzafa, 2009), 387.

10 Wawancara dengan Pembantu Penghulu Desa Cangkring Kecamatan Catigi, 11 September 2018.

11 Wawancara dengan Pembantu Penghulu Desa Cangkring, 11 September 2018. 
suami istri memutuskan untuk bercerai. Munculnya keinginan untuk menikah lagi dari suami atau isteri yang jauh dirantau juga menjadi penyebab perceraian atau suami yang berpoligami saat ditinggal merantau. Bagi istri yang tidak mau dipoligami harus menerima keputusan terberat dalam perkawinannya yaitu perceraian.

Dalam Cerai Lebe hanya dibutuhkan kesepakatan antara pihak suami dan istri yang mau bercerai kemudian dikeluarkan surat talak oleh suami atau surat talak dikirim terlebih dahulu oleh suami karena berada jauh dirantau. Hak talak pada laki-laki serta pernikahan yang dilakukan secara 'sirri' menyebabkan sulitnya perempuan untuk mempertahankan rumah tangganya, sehingga perempuan bersikap permisif terhadap perceraian di bawah tangan. Berdasarkan teori aksi sosial di dapat dilihat bahwa aktor dalam penelitian ini adalah aktor yang memilih perceraian secara adat Cerai Lebe yang dianggap lebih mudah untuk mencapai tujuannya yaitu perceraian. Melalui Cerai Lebe masyarakat diberi kemudahan karena aturan-aturan dalam Cerai Lebe tidak serumit proses perceraian di pengadilan agama dan hal ini dikarenakan pengetahuan mereka tentang perceraian, kondisi sosial budaya dan ekonomi masyarakatnya. Nilai-nilai yang dipegang seorang aktor serta menjadi dasar untuk memutuskan suatu tindakan. Tindakan ini juga dibatasi oleh kendala ekonomi dan pengetahuan, sehingga menyebabkan masyarakat lebih memilih proses perceraian melalui Cerai Lebe.

\section{d. Letak Geografis}

Sejak dahulu Desa Cangkring adalah sebuah laut yang sangat luas, pada ada zaman para wali laut itu digunakan sebagai jalur utama pelayaran dari kerajaan Majapahit ke kerajaan Demak. Secara geografis letak desa Cangkring adalah pinggir pantai sebelah utara laut jawa. Dari segi jarak desa Cangkring sangat jauh dari pusat kota Indramayu terlebih dari kantor Pengadilan Agama Kabupaten Indramayu. Hal ini menjadi suatu yang dapat dipahami jika masyarakat desa Cangkring akan berpikir berat jika mengurus perceraiannya ke Pengadilan karena jarak yang jauh menyebabkan disamping tenaga dan waktu untuk pulang pergi juga akan memakan biaya yang tidak sedikit. Dari sinilah salah satu pertimbangan aparat desa dalam hal ini Lebe mengakomodir permasalahan perceraian demi ketertiban masyarakat dari pada mereka bercerai secara liar yang berdampak negative lebih besar.

e. Pengaruh Pihak Ketiga

Di masyarakat Cangkring terdapat juga perceraian dipengaruhi pihak ketiga, bahkan ada bekas suami yang sampai gila akibatnya. Karena api selalu ditiup oleh kaluarga dan sampai menyala akhirnya suami dengan emosinya mentalakkan isterinya menjadi talak satu, sesampai habis iddah bekas isteri menikah dengan orang lain, pada hal suaminya masih mau merujukinya. Namun apa daya sang isteri sudah terlalu banyak disakiti oleh keluarga bekas suami. Pihak ketiga seharusnya bersikap mendamaikan suami-isteri yang berselisih, Islam telah memberi aturan tentang tahkim/mediasi dengan mendatangkan tokoh masyarakat, ulama atau utusan nenek mamak kedua belah pihak suami-isteri yang menjadi juru damai. Di masyarakat Cangkring terdapat juga penerapan tahkim terhadap percekcokan keluarga, sesuai dengan hasil wawancara peneliti dengan salah seorang tokoh masyarakat:

"Di desa ini sebelum terjadinya perceraian maka di datangkan hakam utusan dari masingmasing kedua belah pihak sebanyak dua oran,. Kadangkala ada yang berhasil didamaikan dan kadangkala ada yang tidak, tergantung kepada peliknya perkara yang dihadapinya. 
Kebanyakan talak terjadi tidak menggunakan mediasi. Bila terjadi perselisihan sang suami dapat menerapkan hak talaknya kepada isteri tampa berpikir panjang." ${ }^{12}$

f. Mahar Murah

Walaupun Islam tidak menganjurkan mahar harus mahal, tapi bagi masyarakat yang kurang memahami arti sebuah perkawinan, sangat mudah sekali menjatuhkan thalak dengan alasan mahar perkawinan mudah terjangkau, membuat kaum laki-laki seenaknya saja kawin cerai, sesuai dengan hasil wawancara peneliti berikut ini:

“Akibat mahar murah, banyak laki-laki yang sudah beristeri yang tidak memahami hukum perkawinan pergi ke kampung-kampung lain kenalan dengan perempuan, mengaku masih bujangan akhirnya menikah, kalau ditanya anda sudah punya isterikan di kampung anda, jawabnya sudah saya tinggalkan (talak). Kenapa hal ini terjadi karena murahnya biaya perkawinan dibandingkan biaya rujuk..$^{13}$

g. Budaya Sosial

Bagi masyarakat awam, yang kurang memahami arti perkawinan, dianggapnya hanya sekedar memenuhi kebutuhan biologis semata, sehingga mudah sekali mentalak isterinya dan kurang memperhatikan akibatnya dan talak dijadikan sebagai senjata untuk menakut-nakuti sang isteri agar selalu tunduk kepada sang suami. Dan sang suami mencari wanita yang lain lagi semaunya. Dan tidak jarang seorang laki-laki sudah pernah menikah sudah beberapa kali begitu juga wanita konon ceritanya sudah pernah menikah 9 kali.

Kebanyakan masyarakat Cangkring enggan pergi ke Pengadilan Agama, dikarenakan biaya mahal, administrasi rumit, memakan waktu lama, akhirnya memilih talak liar dengan alasan secara hukum Islam sudah sah, dan inilah kebiasaan yang telah menjadi budaya masyarakat sejak zaman dahulu. Walaupun kehadiran UU No. 11974 sebagai hukum positif telah lama ada, namun sangat disayangkan masih terdapat umat Islam yang mendua, sebagian sadar hukum dan mentaatinya dan sebagian yang lain meremehkan hasil UUP yang monomental tersebut dengan menilai aturan tersebut sebagai aturan negara yang mempersulit mereka, sehingga mereka melakukan nikah di bawah tangan, talak. liar, dan rujuk liar yakni pelaksanaannya diadakan di luar sistem yang diatur oleh negara, ini semua dapat membawa efek negatif di kalangan umat Islam Indonesia. ${ }^{14}$ Kebanyakan masyarakat awam tidak terbiasa berurusan administrasi, sehingga tidak mengenali apa itu fungsi Pangadilan Agama, sesuai apa yang diungkapkan oleh salah seorang tokoh masyarakat. Menurutnya bahwa masyarakat melakukan Cerai Lebe karena malas berurusan administrasi di Pengadilan Agama disebabkan sumber daya manusia yang rendah, sehingga mereka memilih Cerai Lebe yang sudah menjadi budaya masyarakat berurat-berakar dari zaman dahulu yang dianggapnya biasa-biasa saja tanpa menelusuri akibatnya. ${ }^{15}$

12 Wawancara dengan Pembantu Penghulu Desa Cangkring, 13 September 2018.

13 Wawancara dengan Pembantu Penghulu Desa Cangkring, 10 September 2018.

14 Syamsul Hadi Irsyad, "Akibat Putusnya Perkawinan Karena Perceraian: Selayang Pandang Atas Putusan Mahkamah Agung Mengenai Harta Bersama, Mut'ah, 'Iddah, Hadhanah, Dan Penerapan PP 10/1983 Jo PP 45/1990,” Suara Uldilag: Mahkamah Agung Lingkungan Peradilan Agama 2, no. 1 (2003).

15 Wawancara dengan Ketua KUA Kecamatan Cantigi, 13 September 2018. 


\section{Dampak Cerai Lebe dalam Masyarakat}

\section{Terhadap Keluarga Kedua Belah Pihak}

Dengan terjadi Cerai Lebe tidak saja berimbas terhadap pasangan suami-isteri dan anak tapi juga terhadap keluarga kedua belah pihak. Kadangkala keluarga ikut mencampuri urusan perceraian, sehingga terjadi perang mulut, dendam bahkan sampai berkepanjangan turun-temurun dan mengungkit-ungkitkan hal-hal masa lalu, ironisnya kadang sampai meninggal dunia tetap tidak melakukan tegur-sapa.

\section{Terhadap Anak}

Kebanyakan ahli sosiologi berpendapat diantara faktor yang paling penting dalam membina masyarakat adalah masalah prkawinan, putusnya perkawinan tidak hanya berdampak kepada keluarga tersebut tetapi juga terhadap masyarakat, karena kebanyakan kenakalan remaja berasal dari keluarga yang hubungan kedua orang tuanya sudah bercerai. ${ }^{16}$ Kebanyakan mantan suami begitu saja melepaskan tanggung jawabnya atas nafkah anak pasca perceraian. Kondisi ini telah memaksa kaum perempuan untuk memikul tanggung peran ganda, yakni sebagai ibu rumah tangga, sebagai kepala keluarga. Bila ibu ini tidak mempunyai kemampuan untuk memberi nafkah anak tersebut, ibu cenderung mengeksploitasi anak-anaknya untuk mencari nafkah.

\section{Terhadap Masyarakat}

Perceraian dan kenakalan remaja merupakan masalah sosial, masalah sosial merupakan akibat dari interaksi sosial antara individu, antara individu dengan kelompok, atau antar kelompok. Perceraian seringkali menjadi penghambat pendidikan untuk sampai ke tingkat yang lebih tinggi, dikarenakan orang tua anak telah bercerai dan masing-masing mereka telah menikah dengan orang lain sementara anak merasa takut terhadap ibu tiri dan bapak tiri untuk memperoleh biaya pendidikan. Akhirnya anak tersebut menganggur dan tidak jarang terjadi melaksanankan perkawinan di usia dini, sadisnya kadangkala tidak bertahan lama, karena belum puas menjalani masa remaja dan ketidakmatangan pola pikir.

\section{Terhadap Agama}

Dilemanya yang terjadi di tengah masyarakat Cangkring, Cerai Lebe dianggap biasa-biasa saja, karena sejak dahulu talak dijalankan seperti ini sesuai dengan apa yang tertera dalam kitab-kitab fiqih. Fiqih merupakan pedoman dalam kehidupan bermasyarakat dan dikembangkan secara berkelanjutan sehingga menjadi tradisi karena disosialisasikan secara sturuktural maupun fungsional. Umat Islam memandang fiqih adalah Islam itu sendiri. Fiqih bukan hanya paradigma yang dijadikan rujukan perilaku, melainkan juga sebagai rujukan elastis berprilaku. Padahal hukum yang diproduksi oleh figih dapat berubah karena situasi dan kondisi. Perubahan hukum berarti pula perubahan perilaku beragama dan prilaku berbudaya sepanjang tidak menyimpang dengan ketentuan syari'at. ${ }^{17}$

Bila diperhatikan prilaku masyarakat Cangkring, dalam mempraktik hukum perkawinan Islam, ini muncul dari prilaku beragama dalam konteks masyarakat Muslim didasarkan pada pendekatan prilaku masa lalu. Dalam memahami prilaku masyarakat ini juga merujuk kepada al-'urf

\footnotetext{
${ }_{16}$ Abdul Manan, Aneka Masalah Hukum Perdata Islam Di Indonesia (Jakarta: Kencana, 2008), 8.

17 QS. Al-Talaq (65): 6. "Dan jika mereka (isteri-isteri yang sudah dithalak) itu sedang hamil maka berikanlah kepada mereka nafkanya hingga mereka bersalin".
} 
yakni kebiasaan-kebiasan masyarakat yang bersifat nomatif. Kebiasaan dapat dijadikan titik tolak berprilaku, sebagaimana kaidah "al'adatu muhakkmah" adat dijadikan hukum dalam berperilaku, dan adat ini tidak bisa bertentangan dengan hukum Islam. ${ }^{18}$ Berdasarkan pengertian adat istiadat maka Cerai Lebe dapat dikategorikan sebagai adat istiadat masyarakat Desa Cangkring, sehingga Cerai Lebe ini dapat bertahan dan dilaksanakan oleh masyarakat terutama bagi masyarakat yang nikah liar atau nikah siri. Nikah liar pada masyarakat Desa Cangkring berujung kepada Cerai Lebe, karena Cerai Lebe yang dapat ditempuh oleh masyarakat di Desa Cangkring untuk menyelesaikan konflik yang ada dalam perkawinan dengan status nikah liar. Surat talak yang dikirim oleh suami dianggap sah sebagai bukti Cerai Lebe, karena nikah yang dilakukan oleh pasangan tersebut adalah nikah liar. Surat talak dari suami tadi yang dapat digunakan untuk melangsungkan pernikahan selanjutnya, namun ada juga yang tidak ada surat talak sehingga pernikahan selanjutnya dilakukan di bawah tangan atau nikah liar. Hal ini menjadi siklus perkawinan dan perceraian yang berlaku dalam masyarakat Desa Cangkring.

Tujuan disyari'atkan hukum Islam, agar umat Islam memahami serta mengamalkannya, supaya tujuan hidup bahagia dunia akhirat tercapai. Untuk itu, salah satu hikmah talak harus diucapkan di depan sidang Pengadilan Agama, ${ }^{19}$ agar tercapainya maqashid syari'ah. Undang-undang No 1 Tahun 1974 tentang Perkawinan merupakan undang-undang yang dijadikan sebagai rujukan dalam menyelesaikan segala permasalahan yang terkait dengan perkawinan atau nikah, talak, cerai, dan rujuk. Undang-undang ini merupakan hasil usaha untuk menciptakan hukum nasional dan merupakan hasil unifikasi hukum yang menghormati adanya variasi berdasarkan agama. Unifikasi hukum ini bertujuan untuk melengkapi segala yang hukumnya diatur dalam agama tersebut. ${ }^{20}$

\section{Analisis Yuridis Sosiologis Praktik Cerai Lebe sebagai Inisiatif Lokal dalam Meminimalisir Perceraian Liar}

Menurut UU No. 1/1974 pasal 115 menyatakan bahwa "perceraian hanya dapat dilakukan di depan sidang pengadilan yang berwenang, setelah pengadilan yang bersangkutan berusaha dan tidak berhasil mendamaikan kedua belah pihak". ${ }^{21}$ Namun Cerai Lebe yang ada di Desa Cangkring merupakan proses penyelesaian peceraian yang dilaksanakan dengan melibatkan tokoh adat yaitu Lebe tanpa melibatkan pengadilan agama sebagai lembaga resmi yang menangani masalah perceraian. Perceraian secara adat merupakan fenomena yang ada di daerah Indramayu, khususnya Desa Cangkring. Dengan teori tindakan sosial Max Weber berorientasi pada motif dan tujuan pelaku. Dengan menggunakan teori ini kita dapat memahami perilaku setiap individu maupun kelompok bahwa masing-masing memiliki motif dan tujuan yang berbeda terhadap sebuah tindakan yang dilakukan. Teori ini bisa digunakan untuk memahami tipe-tipe perilaku tindakan setiap individu maupun kelompok. Dengan memahami perilaku setiap individu maupun kelompok, sama halnya kita telah menghargai dan memahami alasan-alasan mereka dalam melakukan suatu tindakan. Sebagaimana diungkapkan oleh Weber, cara terbaik untuk memahami berbagai kelompok

\footnotetext{
18 Bagir Manan, Reformasi Hukum Islam Di Indonesia (Jakarta: Raja Grafindo Persada, 2006), 296-7.

19 Beni Ahmad Saebani and Syamsul Falah, Hukum Perdata Islam Di Indonesia (Bandung: Pustaka Setia, 2011), 94.

20 Abdul Halim Barkatullah and Teguh Prasetyo, Hukum Islam Menjawab Tantangan Zaman Yang Terus Berkembang (Yogyakarta: Pustaka Pelajar, 2006), 146.

${ }^{21}$ Instruksi Presiden Nomor 1 Tahun 1991 tentang Kompilasi Hukum Islam di Indonesia.
} 
adalah menghargai bentuk-bentuk tipikal tindakan yang menjadi ciri khasnya. Sehingga kita dapat memahami alasan-alasan mengapa warga masyarakat tersebut bertindak..$^{22}$

Selanjutnya masalah Cerai Lebe ini dapat dianalisis melalui teori aksi (action theory) oleh Talcott Parsons. Istilah "action" menyatakan secara tidak langsung suatu aktivitas, kreativitas dan proses penghayatan individu. ${ }^{23}$ Berdasarkan teori aksi sosial aktor yang memilih perceraian secara adat (Cerai Lebe) yang dianggap lebih mudah untuk mencapai tujuannya yaitu perceraian. Melalui Cerai Lebe masyarakat diberi kemudahan karena aturan-aturan dalam Cerai Lebe tidak serumit proses perceraian di pengadilan agama dan hal ini dikarenakan pengetahuan mereka tentang perceraian, kondisi sosial budaya dan ekonomi masyarakatnya. Aktor bertindak sesuai dengan pengalaman yang ia dapat dalam bermasyarakat, serta dipengaruhi oleh norma-norma yang berlaku dalam masyarakat. Norma yang berlaku dalam masyarakat mempengaruhi bagaimana seorang aktor untuk bertindak. Cerai Lebe merupakan aturan yang mengatur sistem kehidupan masyarakat di Desa Cangkring, serta banyaknya pengalaman yang diperoleh dari interaksi dengan masyarakat juga menyebabkan aktor tetap mempertahankan Cerai Lebe di masyarakat Desa Cangkring. Pengalaman itu berpengaruh pada nilai-nilai yang dipegang seorang aktor serta menjadi dasar untuk memutuskan suatu tindakan.

Perceraian merupakan sebuah proses penyelesaian konflik dalam perkawinan. Perceraian juga merupakan suatu proses yang menyangkut banyak aspek seperti emosi, ekonomi, sosial dan pengakuan secara resmi oleh masyarakat melalui hukum yang berlaku. ${ }^{24}$ Banyak alasan bagi pasangan suami istri untuk memilih jalan penyelesaian perceraian.

Perceraian menggambarkan situasi dan kondisi menjelang perceraian yang diawali dengan mandeknya proses negoisasi antara pasangan suami-istri. Dalam memilih cara penyelesaian perceraian ini bergantung pada pilihan pasangan yang akan bercerai tersebut. Menurut Ritzer aktor yang mengejar tujuan dalam situasi di mana norma-norma mengarahkannya dalam memilih cara dan alat untuk mencapai tujuan. Norma-norma itu tidak menetapakan pilihan tetapi ditentukan oleh kemampuan aktor untuk memilih. Kemampuan inilah yang disebut Parsons sebagai voluntarism yaitu kemampuan individu menetapakan cara atau alat dari sejumlah alternatif yang tersedia dalam rangka mencapai tujuannya.

Parsons menyusun skema unit-unit dasar tindakan sosial dengan karakteristik sebagai berikut:

1. Adanya individu selaku aktor

2. Aktor dipandang sebagai pemburutujuan-tujuan tertentu

3. Aktor mempunyai alternatif cara, alat serta teknik untuk mencapai tujuannya.

4. Aktor berhadapan dengan sejumlah kondisi situasional yang dapat membatasi tindakannya dalam mencapai tujuan. Kendala tersebut berupa situasi dan kondisi, sebagian ada yang dapat dikendali oleh individu.

5. Aktor berada di bawah kendala nilai-nilai, norma-norma dan berbagi ide abstrak yang mempengaruhinya dalam memilih dan menentukan tujuan serta tindakan alternatif untuk mencapai tujuannya. ${ }^{25}$

\footnotetext{
22 Pip Jones, Pengantar Teori-Teori Social: Dari Teori Fungsionalisme Hingga Post-Modernisme, ed. Saifuddin (Jakarta: Pustaka Obor, 2003), 15.

${ }_{23}$ George Ritzer, Sosiologi Ilmu Pengetahuan Berparadigma Ganda (Jakarta: Raja Grafindo Persada, 2003), 48.

24 Bani Syarif Maula, "Kajian Al-Ahwal Al-Syakhsiyyah Dengan Pendekatan Maqasid Al-Syari'ah,” Al-Manahij:Jurnal Kajian Hukum Islam 8, no. 2 (2014): 233-46.

25 Ritzer, Sosiologi Ilmu Pengetahuan Berparadigma Ganda, 49.
} 
Dalam kasus perceraian melalui lebe merupakan pilihan bagi masyarakat dalam menyelesaiakan konflik yang ada dalam perkawinan. Banyak alasan memilih Cerai Lebe, baik itu alasan individu itu sendiri, ekonomi ataupun kondisi sosial budaya setempat yang mempengaruhi seorang untuk menyelesaikan perceraian secara Cerai Lebe. Banyak orang berpendapat bahwa perceraian itu merupakan krisis dan kegagalan dalam perkawinan. Suatu perkawinan dimaksudkan untuk membentuk dan membina keluarga bahagia dan sejahtera sepanjang masa, namun kenyataan hidup membuktikan bahwa tujuan di atas tidaklah mudah untuk dicapai, bahkan tidak jarang suatu perkawinan yang didambakan mengalami kegagalan. Menurut Goode masyarakat mempunyai defenisi yang berbeda tentang konflik antara pasangan suami istri serta cara penyelesaiannya. Goode sendiri berpendapat bahwa pandangan yang menggap perceraian merupakan kegagalan adalah bias, karena semata-mata mendasarkan perkawinan pada cinta yang romantis. Padahal semua sistem perkawinan paling sedikit terdapat dua orang yang hidup dan tinggal bersama di mana masing-masing memiliki keinginan, kebutuhan, nafsu dan latar belakang dan nilai sosial yang bisa saja berbeda satu sama lain. Akibatnya sistem ini bisa muncul ketegangan-ketegangan dan ketidak- bahagian yang dirasakan oleh anggota keluarga, karenanya apabila terjadi sesuatu dengan perkawinan (misalnya perceraian) maka akan timbul masalah-masalah yang harus dihadapi baik oleh pasangan yang bercerai maupun anak-anak serta masyarakat di wilayah terjadinya perceraian. ${ }^{26}$

Masyarakat di Desa Cangkring 100\% menganut agama Islam sehingga syariat Islam yang berlaku mengatur tata cara perceraian yang sah selain secara adat. Hukum Islam membolehkan cerai jika hal ini akan membawa kemaslahatan kedua belah pihak. Pihak yang ingin bercerai untuk mengambil prakarsa mengajukan permohonan pemutusan hubungan perkawinan ke pengadilan agama yang mewilayahinya, dengan perantara hakim perkawinan dapat diputuskan terhadap suatu perkara yang diajukan oleh suami atau isteri. Dalam kenyataan di masyarakat, masih banyak yang melakukan perceraian secara adat yang disebut Cerai Lebe. Cerai Lebe merupakan alternatif cara perceraian yang ditempuh oleh masyarakat di desa Cangkring dalam menyelesaikan perkara perceraian. Cerai Lebe yang ada di masyarakat Desa Cangkring tetap bertahan sampai sekarang dan menjadi terlembaga dalam kehidupan masyarakat. Dari hasil penelitian yang dilakukan pada masyarakat Desa Cangkring yang melakukan Cerai Lebe dan tokoh masyarakat sekitarnya diketahui bahwa alasan bertahannya Cerai Lebe di masyarakat Desa Cangkring sebagaimana yang telah dijelaskan diatas adalah kondisi ekonomi. Alasan inilah yang menguatkan pertimbangan masyarakat Desa Cangkring untuk memilih Cerai Lebe adalah biaya perceraian yang murah. Biaya untuk Cerai Lebe lebih murah dibandingkan dengan di pengadilan agama.

Perkara perceraian secara adat terdapat tata cara yang diakui secara adat, yang menjadi hukum adat yang mengatur masyarakat yang akan melakukan perceraian secara adat. Pengucapan ikrar talak dapat dilakukan di depan Lebe atau dengan cara mengirim surat talak dari suami. Surat talak itu menjadi bukti perceraian telah terjadi, namun untuk mendapat pengakuan dari masyarakat Desa Cangkring harus dilakukan di depan Lebe untuk menyelesaikan persoalan harta dan menghindari konflik keluarga. Surat talak dalam hukum resmi yang mengatur perceraian adalah surat ikrar talak yang dikirim oleh pengadilan agama. ${ }^{27}$ Menurut pendapat Hilman, sebagaimana dikutip Suhendi, 28 "tingkat perceraian tertinggi berada pada kategori pekerja kasar, seperti buruh,

26 T.O. Ihromi, Bunga Rampai, Sosiologi Keluarga (Jakarta: Yayasan Obor Indonesia, 2004), 135-6.

27 Instruksi Presiden Nomor 1 Tahun 1991 tentang Kompilasi Hukum Islam di Indonesia. Pasal 131 ayat 3 dan 5.

${ }^{28}$ Hendi Suhendi and Ramadani Wahyu, Pengantar Studi Sosiologi Keluarga (Bandung: Pustaka Setia, 2001), 135. 
pembantu rumah tangga, dan pelayan restoran". Menurut Goode "tingkat perceraian juga terjadi pada tingkat pendidikan dan penghasilan. Hal ini menunjukkan adanya konsistensi antara status pekerjaan dengan tingkat pendidikan menjadi pemicu perceraian". ${ }^{29}$ Masyarakat Desa Cangkring yang 70\% bekerja sebagai buruh, penghasilan sebagai buruh tidak mencukupi kebutuhan hidup sehari-hari, karena kondisi ekonomi keluarga yang seperti ini dikatakan Goode sebagai pemicu perceraian. Kondisi ekonomi yang berpenghasilan rendah menyebabkan masyarakat lebih memilih Cerai Lebe dari pada menempuh jalur resmi dalam menyelesaikan perakara perceraian. Fenomena Cerai Lebe pada masyarakat Cangkring masih tetap bertahan karena aktor berhadapan dengan sejumlah kondisi situasional yang mendukung tindakannya untuk Cerai Lebe. Aktor dalam penelitian ini adalah pasangan yang melakukan Cerai Lebe. Masyarakat mengetahui adanya hukum yang sah yang mengatur perceraian di Pengadilan Agama Sungai Penuh, namun keterbatasan kondisi ekonomi masyarakat menyebabkan enggan untuk melakukan perceraian di pengadilan agama. Cerai Lebe dianggap lebih sesuai dengan kondisi ekonomi masyarakat. Masyarakat Desa Cangkring yang ingin melakukan perceraian lebih memilih cara ini untuk mencapai tujuan yang sesuai dengan nilai dan norma yang berlaku dalam masyarakat ini, yaitu perceraian secara adat (Cerai Lebe).

Menurut Talcott Parsons tindakan sosial merupakan suatu proses di mana aktor terlibat dalam pengambilan keputusan-keputusan subyektif tentang saran dan cara untuk mencapai tujuan tertentu yang telah dipilih, yang kesemuanya dibatasi kemungkinan- kemungkinannya oleh sistem kebudayaan dalam bentuk norma-norma, ide-ide dan nilai-nilai sosial. ${ }^{30}$ Pasangan yang lebih memilih Cerai Lebe didasari oleh keputusan subyektif yang dibatasi oleh kondisi ekonomi masyarakat dan nilai-nilai yang mengatur tentang Cerai Lebe. Melalui cara ini aktor dapat mencapai tujuannya untuk menyelesaikan konflik perkawinan. Cara ini tidak menggangu ketertiban dalam sistem masyarakat Desa Cangkring, namun ini menunjukan rendahnya supremasi hukum resmi negara yang mengatur perceraian.

Perceraian yang terjadi di Desa Cangkring, sah menurut agama Islam dan adat yang berlaku tapi tidak sah secara hukum resmi negara. Salah satu yang menjadi alasan masyarakat untuk bercerai secara adat (Cerai Lebe) di Desa Cangkring adalah pernikahan yang mereka jalani sebelumnya dikarenakan pernikahan siri. Nikah siri di Masyarakat di Desa Cangkring disebut nikah kyai. Pernikahan liar yang dilakukan masyarakat Desa Cangkring juga dikarenakan kondisi ekonomi, masyarakat yang tidak mampu membiayai proses pernikahan secara resmi. Alasan lain terjadinya nikah siri karena adanya keinginan berpoligami. Pernikahan sirri (nikah liar) sebagai alasan untuk melakukan perceraian secara adat. Cerai Lebe tetap bertahan dan dipilih oleh warga Desa Cangkring berdasarkan kebiasaan masyarakat dahulu dan alasan kemudahan akses untuk menyelesaikan masalah perkawinan. Banyak masalah yang ditimbulkan oleh nikah liar karena tidak mempunyai kekuatan hukum untuk sebuah ikatan atau perceraian pasangan suami isrti. Nikah liar yang dilakukan oleh masyarakat, maka perceraian hanya dapat dilakukan melalui Cerai Lebe. Proses Cerai Lebe tidak membutuhkan akta nikah, sehingga prosesnya lebih mudah. Cerai Lebe dibuktikan dengan adanya surat talak dari suami, tapi ada juga hanya pengucapan ikrar talak. Surat cerai yang sah menurut hukum resmi adalah surat cerai yang dikeluarkan oleh Pengadilan Agama, namun masyarakat tidak terlalu memikirkan syahnya sebuah perceraian, hal ini dikarenakan

\footnotetext{
29 Suhendi and Wahyu, 135.

30 Suhendi and Wahyu, 49-50.
} 
kesadaran hukum yang masih rendah di masyarakat. Berdasarkan tingkat pendidikan terdapat 45,81\% masyarakat Desa Cangkring yang tidak sekolah. Pengetahuan masyarakat tentang dampak perceraian di bawah tangan juga tidak didukung oleh informasi penyuluhan dari pemerintah. Karena penyuluhan hanya dilakukan di tingkat kecamatan. Alasan lain yang menyebabkan masyarakat Desa Cangkring mengabaikan keabsahan sebuah perceraian dikarenakan kebiasaan dari masyarakat yang menyelesaikan perceraian dengan proses Cerai Lebe merupakan kebiasaan turun-temurun dan telah menjadi adat yang mengatur kehidupan masyarakat Desa Cangkring dan masyarakat menganggap Cerai Lebe sebagai adat mereka. Perceraian merupakan salah satu cara untuk menyelesaikan konflik yang ada dalam keluarga. Murdock, dikutip Ihromi, menyimpulkan bahwa "di setiap masyarakat terdapat institusi/lembaga yang menyelesaikan proses berakhirnya suatu perkawinan sama halnya dengan mempersiapkan perkawinan". ${ }^{31}$ Berdasarkan pendapat dari Murdock dapat dikatakan bahwa di setiap kehidupan masyarakat baik itu di kota maupun di desa memiliki lembaga untuk menyelesaikan proses perceraian.

Cerai Lebe juga sudah menjadi Adat Istidat Masyarakat Perkembangan tata cara bercerai yang sudah diatur oleh pemerintah tidak mempengaruhi keberadaan Cerai Lebe di masyarakat Desa Cangkring. Hal ini terlihat bahwa masyarakat menganggap Cerai Lebe sudah merupakan adat yang mengatur masalah perceraian. Cerai Lebe dianggap masyarakat sebagai cara untuk menyelesaikan perceraian yang diakui oleh masyarakat dan aturan-aturannya dapat diterima masyarakat. Cerai Lebe sudah menjadi kebiasaan yang terpola dalam kehidupan masyarakat Desa Cangkring. Kebiasaan yang dijadikan dasar hubungan antara orang-orang tertentu sehingga tingkah laku atau tindakan masing-masing dapat diatur dan menimbulkan norma atau kaidah. Norma atau kaidah yang timbul dari masyarakat sesuai dengan kebutuhannya disebut adat istiadat (custom). ${ }^{32}$

Adanya Supremasi Hukum juga menimbulkan praktik Cerai Lebe berlangsung sampai sekarang Kesadaran hukum masyarakat merupakan perasaan hukum dan keyakinan hukum individu dalam masyarakat yang merupakan kesadaran hukum individu, dan merupakan pangkal dari kesadaran hukum masyarakat. ${ }^{33}$ Kesadaran hukum merupakan sebuah bentuk keyakinan masyarakat terhadap hukum yang berlaku. Perceraian melalui Lebe merupakan bentuk dari sebuah aturanaturan yang berlaku dalam sebuah masyarakat, yang didasarkan pada aspek sosiologis kehidupan masyarakatnya. Pilihan masyarakat untuk bercerai dengan Cerai Lebe secara tidak langsung ini termasuk dalam bentuk kesadaran terhadap hukum resmi yang masih rendah. Supremasi hukum yang masih rendah ditandai dengan kurangnya kesadaran terhadap kaidah-kaidah hukum resmi yang mengatur tentang perceraian. Faktor-faktor lain yang menyebabkan rendahnya supremasi hukum resmi dalam masyarakat Desa Cangkring yaitu kondisi ekonomi dan pengetahuan masyarakat yang rendah tentang hukum resmi.

Menurut Parsons integrasi dalam sebuah sistem diperlukan proses institusionalisasi agar pola relasi yang stabil antar aktor yang mempunyai status dan peran yang berbeda dapat terwujud. Melalui proses institusionalisasi ini, internalisasi norma, kebiasaan, dan peran dapat dilakukan sehingga dapat menghasilkan kepribadian aktor yang dapat mewujudkan ketertiban sosial. Proses internalisasi norma menjadi pilihan masyarakat karena prosesnya yang tidak membutuhkan waktu

\footnotetext{
Ihromi, Bunga Rampai, Sosiologi Keluarga, 135.

32 Soerjono Soekamto, Pengantar Sosiologi (Jakarta: Raja Grafindo Persada, 2006), 157.

33 Soerjono Soekamto, Pokok-Pokok Sosiologi Hukum (Jakarta: Raja Grafindo Persada, 1990), 167.
} 


\section{يl'Manāhij}

yang lama, yaitu hanya membutuhkan minimal satu kali duduk, jika semua syarat yang diajukan kedua belah pihak terpenuhi maka proses Cerai Lebe dapat dilakukan. Hal ini juga didukung oleh anggapan masyarakat bahwa perceraian di pengadilan agama memerlukan proses waktu yang lama. Aturanaturan adat yang mengatur sistem perceraian yang tetap dilaksanakan oleh masyarakat. Cerai Lebe merupakan tahap-tahap perceraian berdasarkan norma adat di masyarakat Desa Cangkring, normanorma ini berfungsi untuk menciptakan ketertiban dalam kehidupan bermasyarakat.

Pada dasarnya menurut hukum positif di Indonesia, Cerai Lebe tidak mendapat pengakuan dan perlindungan oleh hukum beserta akibat-akibatnya, karenanya tidak mempunyai kekuatan hukum sebab dilakukan tidak sesuai menurut aturan hukum. Hasil analisa, ketentuan penjatuhan talak harus dilakukan di depan sidang Pengadilan Agama adalah tidak bertentangan dengan prinsip-prinsip dasar hukum Islam karena lebih membawa terwujudnya tujuan hukum yaitu kemaslahatan. Sebaliknya Cerai Lebe akan lebih terbuka untuk terjadinya kemudharatan berupa tidak ditaatinya aturan hukum talak. Atas dasar itu cerai talak di Pengadilan Agama wajib hukumnya, sedangkan cerai talak di bawah tangan kalaulah tidak sampai haram paling tidak dapat dikatagorikan makruh hukumnya. Hendaknya bagi instansi terkait agar lebih meningkatkan kualitas maupun kuantitas pelaksanaan penyuluhan hukum pada masyarakat dan materi- materinya meliputi dasardasar falsafah hukum Islam korelasinya dengan hukum positif berkenaan dengan masalah talak. Hendaknya peraturan hukum yang mengatur bahwa talak hanya dapat dilakukan di Pengadilan Agama dapat di pertahankan karena tidak bertentangan dengan prinsip-prinsip hukum Islam. Karena itu bagi masyarakat hendaknya mematuhi dan mentaatinya.

Orang-orang yang tidak menghormati lembaga perkawinan dan lembaga hukum Indonesia akan mudah mengaku-ngaku bahwa mereka telah kawin dengan syarat dan rukun yang telah ditentukan (dengan surat cerai), padahal surat itu adalah hanya surat talak (talak raj'i). Banyak ahli waris yang nantinya berhak atas waris, tetapi lemah tuntutannya karena tidak ada bukti. Begitu juga sebaliknya, orang yang bukan ahli waris bisa saja mengklaim dirinya sebagai ahli waris. Kemudian juga akan ada menimbulkan banyak mudharat dalam hal nasab. Akibat lebih lanjut adalah pengadilan akan mendapat kesulitan dalam menyelesaikan masalah sengketa rumah tangga dan masalah kewarisan.

Bentuk Cerai Lebe di Desa Cangkring Kabupaten Indramayu bukanlah cerai secara legal menurut aturan perundang-undangan. Oleh karena itu, solusi yang dapat diberikan adalah hendaknya pemahaman masyarakat tentang legalitas hukum perceraian maupun pernikahan dapat ditingkatkan, agar masyarakat dapat mengetahui manfaat dari perceraian yang sah/legal secara hukum agar terjamin keadilan bagi masing-masing yang berperkara dan dampak negatif dari adanya perceraian liar. Mengingat kemungkinan dampak negatif dari perkawinan dengan cara perceraian liar yang sangat besar, maka sudah barang tentu bahwa Pengadilan Agama merupakan lembaga yang sangat penting sebagai sarana untuk menyelesaikan perkara perceraian. Dan juga lembaga KUA dalam hal ini adalah pembantu PPN, merupakan lembaga yang memiliki peran penting dan strategis sebagai wadah atau tempat dimana seseorang yang akan melangsungkan perkawinan agar mendaftarkan diri secara benar di lembaga tersebut dengan tidak ada pembohongan-pembohongan yang dilakukan oleh pihak pelaku perkawinan ataupun oleh pihak pembantu PPN. Karena pencatatan perkawinan di KUA itu sangat penting dan perkawinan hanya akan menjadi sah apabila dilaksanakan menurut hukum syari'at, dihadapan PPN dan dicatat oleh PPN. 


\section{Penutup}

Dari seluruh uraian pembahasan di atas serta analisis yang terdapat pada setiap pembahasan ini, maka sebagai akhir dari kajian ini, penulis akan menarik sebuah kesimpulan sebagai berikut:

Berdasarkan hukum di Indonesia, segala sesuatu yang bersangkutan dengan kependudukan harus dicatat, termasuk juga masalah perceraian. Perceraian berkaitan erat dengan masalah kewarisan, kekeluargaan, sehingga perlu dicatat untuk menjaga agar ada tertib hukum. Dalam pasal 39 ayat (1) Undang -undang nomor 1 Tahun 1974 dan Pasal 65 Undang undang No. 7 Tahun 1989 ditentukan bahwa "Perceraian hanya dapat dilakukan di depan sidang pengadilan setelah pengadilan yang bersangkutan berusaha dan tidak berhasil mendamaikan kedua belah pihak (suami-isteri). Dalam kenyataannya masih ada sebagian masyarakat di wilayah hukum Pengadilan Agama Kabupaten Indramayu, khususnya di desa Cangkring, melakukan cerai di luar Pengadilan Agama dan cukup dengan Lebe saja. Cerai Lebe yang ada di Desa Cangkring merupakan proses penyelesaian peceraian yang dilaksanakan dengan melibatkan tokoh masyarakat yaitu Lebe tanpa melibatkan Pengadilan Agama sebagai lembaga resmi yang menangani masalah perceraian. Lebe di desa Cangkring (pembantu pegawai pencatat nikah) menjadi fasilitator dan media dalam hal persoalan perceraian di desa tersebut termasuk juga dalam hal menangani secara administratif data masyarakat yang telah bercerai tanpa mengajukan ke Pengadilan Agama.

Berdasarkan penelitian yang dilakukan, ada sebagian masyarakat yang lebih memilih bercerai di depan Lebe dibanding bercerai dalam sidang Pengadilan Agama. Adapun penyebab terjadinya perceraian didepan Lebe di Desa Cangkring Kabupaten Indramayu, banyak dilatar belakangi oleh berbagai faktor. Salah satu faktor perceraian Lebe tersebut dikarenakan sulitnya melakukan pengurusan perceraian di Pengadilan Agama yang membutuhkan waktu yang lama, serta banyak mengeluarkan biaya. Faktor lainnya yang menjadi sebab adalah perkawinan usia dini, sumber daya manusia rendah, ekonomi, pengaruh pihak ketiga, mahar murah, nikah sirri, dan faktor budaya sosial. Sementara dampak dari Cerai Lebe adalah berpengaruh terhadap keluarga, ketertiban masyarakat, dan pemahaman beragama.

Penyelesaian perceraian yang dilakukan secara adat dan tidak melalui proses peradilan merupakan fenomena yang ada di Desa Cangkring. Cerai Lebe merupakan alternatif cara perceraian yang ditempuh oleh masyarakat di desa Cangkring dalam menyelesaikan perkara perceraian. Cerai Lebe yang ada di masyarakat Desa Cangkring tetap bertahan sampai sekarang dan menjadi terlembaga dalam kehidupan masyarakat. Berdasarkan teori aksi sosial aktor (action theory oleh Talcott Parsons) Cerai Lebe merupakan aturan yang mengatur sistem kehidupan masyarakat di Desa Cangkring, serta banyaknya pengalaman yang diperoleh dari interaksi dengan masyarakat juga menyebabkan aktor tetap mempertahankan Cerai Lebe di masyarakat Desa Cangkring. Pengalaman itu berpengaruh pada nilai-nilai yang dipegang seorang aktor serta menjadi dasar untuk memutuskan suatu tindakan. Cerai Lebe dianggap masyarakat sebagai cara untuk menyelesaikan perceraian yang diakui oleh masyarakat dan aturan-aturannya dapat diterima masyarakat. Cerai Lebe sudah menjadi kebiasaan yang terpola dalam kehidupan masyarakat Desa Cangkring. Kebiasaan yang dijadikan dasar hubungan antara orang-orang tertentu sehingga tingkah laku atau tindakan masing-masing dapat diatur dan menimbulkan norma atau kaidah. Perceraian secara adat (Cerai Lebe) merupakan bentuk dari sebuah aturan-aturan yang berlaku dalam sebuah masyarakat, yang didasarkan pada aspek sosiologis kehidupan masyarakatnya. Pilihan masyarakat untuk bercerai dengan Cerai Lebe secara 
tidak langsung ini termasuk dalam bentuk kesadaran terhadap hukum resmi yang masih rendah. Supremasi hukum yang masih rendah ditandai dengan kurangnya kesadaran terhadap kaidah-kaidah hukum resmi yang mengatur tentang perceraian. Faktor-faktor lain yang menyebabkan rendahnya supremasi hukum resmi dalam masyarakat Desa Cangkring yaitu kondisi ekonomi dan pengetahuan masyarakat yang rendah tentang hukum resmi.

Berdasarkan temuan dan kesimpulan di atas, sosialisasi kepada masyarakat tentang legalitas hukum perceraian maupun pernikahan dapat ditingkatkan, agar masyarakat dapat mengetahui hak dan kewajiaban yang sah secara hukum maupun adat dan agama, selain itu juga diberikan pengetahuan tentang dampak negatif dari penyimpangan-penyimpangan hukum. Adanya fenomena penyimpangan-penyimpangan dari aturan hukum khususnya hukum perceraian oleh masyarakat, nampaknya perlu dipahami tidak lagi sekedar dengan kaca mata yuridis, tetapi juga dengan kaca mata sosiologis atau sosiologi hukum, karena akan lebih menghadirkan keadilan yang lebih substantif yang berdasar pada basis etika, moral dan nilai kemanusiaan masyarakat. Hal ini dianggap penting dalam rangka mengukur tingkat efektivitas hukum dalam masyarakat, bukankah hukum yang baik adalah norma yang antisipatif, responsif, mampu beradaptasi dan mengakomodasi perubahan yang terjadi dan kebutuhan masyarakat, tidak disangkal hukum sebagai norma adalah realitas ideal.

\section{DAFTAR PUSTAKA}

Ali, M. Daud. Hukum Islam Dan Peradilan Agama. Jakarta: Raja Grafindo Persada, 2002.

Barkatullah, Abdul Halim, and Teguh Prasetyo. Hukum Islam Menjawab Tantangan Zaman Yang Terus Berkembang. Yogyakarta: Pustaka Pelajar, 2006.

Harahap, M. Yahya. Kedudukan Kewenangan Dan Acara Peradilan Agama UU No. 7 Tahun 1989. Jakarta: Sinar Grafika, 2007.

Ihromi, T.O. Bunga Rampai, Sosiologi Keluarga. Jakarta: Yayasan Obor Indonesia, 2004.

Instruksi Presiden Nomor 1 Tahun 1991 tentang Kompilasi Hukum Islam di Indonesia (n.d.).

Irsyad, Syamsul Hadi. “Akibat Putusnya Perkawinan Karena Perceraian: Selayang Pandang Atas Putusan Mahkamah Agung Mengenai Harta Bersama, Mut'ah, 'Iddah, Hadhanah, Dan Penerapan PP 10/1983 Jo PP 45/1990." Suara Uldilag: Mahkamah Agung Lingkungan Peradilan Agama 2, no. 1 (2003).

Jones, Pip. Pengantar Teori-Teori Social: Dari Teori Fungsionalisme Hingga Post-Modernisme. Edited by Saifuddin. Jakarta: Pustaka Obor, 2003.

Kelsen, Hans. Pengantar Teori Hukum. Bandung: Nusa Media, 2010.

Khoiruddin, Nasution. Hukum Perdata (Keluarga Islam Indonesia) Dan Perbandingan Hukum Perkawinan Di Dunia Muslim. Yogyakarta: Academia - Tazzafa, 2009.

Manan, Abdul. Aneka Masalah Hukum Perdata Islam Di Indonesia. Jakarta: Kencana, 2008.

Manan, Bagir. Reformasi Hukum Islam Di Indonesia. Jakarta: Raja Grafindo Persada, 2006.

Maula, Bani Syarif. "Kajian Al-Ahwal Al-Syakhsiyyah Dengan Pendekatan Maqasid Al-Syari'ah.” AlManahij: Jurnal Kajian Hukum Islam 8, no. 2 (2014): 233-46. 
-- - Sosiologi Hukum Islam Di Indonesia: Studi Tentang Realitas Hukum Islam Dalam Konfigurasi Sosial Dan Politik. Malang: Aditya Media, 2010.

Ritzer, George. Sosiologi Ilmu Pengetahuan Berparadigma Ganda. Jakarta: Raja Grafindo Persada, 2003.

Saebani, Beni Ahmad, and Syamsul Falah. Hukum Perdata Islam Di Indonesia. Bandung: Pustaka Setia, 2011.

Salim, Arskal. Demi Keadilan Dan Kesetaraan. Jakarta: Puskumham dan Asia Foundation, 2009.

Shodiq, M., and Shalahuddin Chaery. Kamus Istilah Agama: Memuat Berbagai Istilah Agama Dari Alquran Hadits Dll. Jakarta: Sienttarama, 1991.

Soekamto, Soerjono. Pengantar Sosiologi. Jakarta: Raja Grafindo Persada, 2006.

--_. Pokok-Pokok Sosiologi Hukum. Jakarta: Raja Grafindo Persada, 1990.

Suhendi, Hendi, and Ramadani Wahyu. Pengantar Studi Sosiologi Keluarga. Bandung: Pustaka Setia, 2001.

Undang-Undang Nomor 1 Tahun 1974 tentang Perkawinan (n.d.). 
